\title{
The Parity Rate of Indoor-Resting Adult Female Anopheles and Culex Mosquitoes and Their Implication in Disease Transmission in Nnamdi Azikiwe University Female Hostels Awka, South Eastern Nigeria
}

\author{
Umeanaeto P.U. ${ }^{1}$, Asogwa A.N. ${ }^{1}$, Onyido A.E. ${ }^{1}$, Irikannu K.C ${ }^{1}$, Ifeanyichukwu M.O. ${ }^{2}$ \\ ${ }^{1}$ Department of Parasitology and Entomology, Faculty of Biosciences, Nnamdi Azikiwe, University Awka, Anambra State, \\ Nigeria \\ ${ }^{2}$ Department of Medical Laboratory Sciences, Faculty of Health Science and Technology, Nnamdi Azikiwe University, Nnewi \\ Campus, Anambra State, Nigeria
}

\begin{abstract}
A study on the parity rate of indoor-resting Anopheles and Culex mosquitoes and their implication in disease transmission was carried out in Nnamdi Azikiwe University female hostel between June and July 2016. The mosquitoes were sampled weekly from 24 randomly selected rooms using pyrethrum knock-down collection (P.K.C). A total of 516 mosquitoes comprising of 4 species: Anopheles gambiae, Anopheles funestus, Culex quinquefasciatus and Culex annulioris, were collected during the study period. The mosquitoes were examined for their abdominal gradings/gonotrophic stages and dissected for parity determination. Culex quinquefasciatus $(61.43 \%)$ constituted the most abundant species followed by Anopheles gambiae (30.04\%) and Anopheles funestus (7.56\%) and the least being Culex annulioris (0.97\%). Results showed that majority of the vector species were fed and parous and variations among the parity rates of the 4 species was significant $(P<0.05)$. The high rate of the fed and parous mosquito species is of utmost concern in the hostel environment and therefore control measures aimed at eliminating the breeding sites and reducing its contact with the students should be embraced and practiced so as to minimize disease transmission among the students.
\end{abstract}

Keywords- Anopheles, female hostel, indoor-resting, mosquitoes, parity.

\section{INTRODUCTION}

Mosquito-borne diseases are major health problems in Nigeria as in other parts of sub-saharan Africa. Apart from malaria, other mosquito-borne diseases have also accounted for huge economic loss, social disgrace, low productivity, absenteeism, sleeplessness among others in many parts of the country (Anosike et al., 2003). Malaria and lymphatic filariasis are mosquito-borne diseases that account for the largest global burden of mortality and morbidity in the world's poorest countries (WHO, 2010). More than half of the world's population is at risk of at least one of the diseases. Malaria is caused by Plasmodium parasite and transmitted by Anopheles mosquitoes. According to the latest estimates from WHO (2015), there were an estimated 438, 000 malaria deaths worldwide. Most of these deaths occurred in the African Region (90\%), followed by the South-East Asia Region (7\%) and the Eastern Mediterranean Region (2\%). It is highly endemic in Nigeria with about $97 \%$ of people at risk of the disease (PMI, 2013). Lymphatic filariasis (LF) which is one of the most debilitating neglected tropical disease (N.T.D) in the world is caused by the parasitic worms:Wuchereria Bancrofti, Brugia malayi and Brugia timori and is transmitted by Anopheles, Culex, Aedes and Mansoni mosquitoes (WHO, 2010). The disease is endemic in 81 countries with an estimated 120 million people infected and 40 million people with clinical manifestations including lymphoedema (elephantiasis) of the limbs and urogenital disorders, especially hydrocoele in men (WHO, 2010). Nigeria bears the highest burden of lymphatic filariasis in Africa, with an estimated 80 to 120 million people at risk (Hotez et al., 2012). It is common to find malaria and lymphatic filariasis in the same human population and sharing the same mosquito vectors (Burkot et al., 1990). It is therefore, 
common to find co-infections of malaria and lymphatic filariasis parasites in a single mosquito vector in these areas. The diseases have been observed to co-exist in some parts of Nigeria, such as New Bussa, Niger State (Awolola et al., 2006). These diseases cause high death toll on both human and animal populations and lead to poor socio-economic development of many countries.

The transmission of mosquito-borne diseases to human by their vectors is achieved through blood-feeding (Kuno, 1995; Lehane, 2005; Scott and Takken, 2012). The mosquito's reproductive cycle starting with the blood-meal and ending with egg-laying, also called the gonotrophic cycle (GC), is continous during the life of the female and is temperature-dependent (Pant et al., 1973; Saifur, 2012). During their bloodmeals, females can ingest the diseasecausing pathogen that will disseminate into the mosquitos' body by passing first into the midgut, then crossing the intestinal barrier, amplifying into the haemocoele and eventually reaching the ovaries and salivary glands. The percentage of females that have already deposited their eggs, called the parous females, increases as the age of the mosquito population increases, concomitantly with the transmission risks. Many studies have attempted to estimate the survival of mosquitoes directly through capture-markrelease-capture (Fouque et al., 2006; Maciel et al., 2007; Harrington et al., 2008) or indirectly with the parity rates assuming a direct relationship between parity rates and survival (Davidson, 1954; Garret-Jones and Grab, 1994; David et al., 2012). The first method although more accurate are not available for routine surveillance. On the contrary, the estimation of parity rates from field collection is more feasible hence the aim of this study.

\section{MATERIALS AND METHODS}

\subsection{Study Area}

The study was conducted from June to July 2016 in Stella Okoli and Dora Akunyili Female hostels of Nnamdi Azikiwe University in Awka, Anambra state. Nnamdi Azikiwe is located in Awka, Awka-south L.G.A, Anambra state. It is a semi-urban area with geographical co-ordinates of $6.25^{\circ} \mathrm{N}$ and $7.12^{\circ} \mathrm{E}$ (Unizik portal.edu.ng). The school is located in the tropical rainforest zone, although it has derived savanna vegetation. The daily temperature ranges from $27^{\circ} \mathrm{C}-30^{\circ} \mathrm{C}$ between June and December but rises to $32^{\circ} \mathrm{C}-34^{\circ} \mathrm{C}$ between January and April, with the last few months of the dry season marked by intense heat. It has a relative humidity of $70 \%$ reaching $80 \%$ during rainy season and an annual rainfall of about $2000 \mathrm{~mm}$ (Iloeje, 2001). The hostels are made up of 98 rooms each with 4 students in each room, is surrounded by tall trees, relatively tall grasses and shrubs. There are ground collections of stagnant water due to rainfall in the rainy season and the side gutters are heavily filled with stagnant waste water from student activities. The collections of water in the environment therefore serve as breeding sites for mosquitoes.

\subsection{Selection of Rooms for Survey}

A cross-sectional design was used to conduct this study. The two female hostels are made up of 196 rooms (98 in each). Twelve rooms were randomly selected from each of the hostels total of 196 rooms; 98 for each hostel, 12 rooms for sampling adult mosquitoes. Rooms selected for study were the ones where people slept prior to Pyrethrum knockdown collection (PKC).

\subsection{Collection of Mosquitoes}

Pyrethrum knock-down collection was employed in collecting the indoor-resting adult mosquitoes. This was conducted thrice in a week in the early morning hours between 6:00 and 8:30am. Prior to the collections, edible and fragile materials were evacuated from the rooms. The floor is covered with a large white sheet. Thereafter, windows and doors were closed and eaves were stuffed to prevent escapees. The room is sprayed with commercial pyrethrum-based aerosol (Raid) on every corner of the rooms in a clockwise direction until the rooms were filled with the insecticidal mist. After 15 minutes, the room was opened and the sheet was carefully picked up at the corners and taken outside. The knocked-down mosquitoes were picked with the aid of forceps and transferred into labelled petri dishes lined with moist cotton wool and filter paper for preservation. The collections were identified in the Department of Parasitology and Entomology Laboratory.

\subsection{Identification and Grading of Mosquito Species}

The collections were identified using gross morphological keys described by Gillet (1972). Sexing of the mosquitoes was done and only the female mosquitoes were retained. The gonotrophic stages/abdominal grading of the species were examined according to the external appearance of the stomach contents as described by WHO (1994). They were classified as unfed, fed, half-gravid and gravid.

\subsection{Dissection of Mosquito Species}

The unfed and fed mosquitoes were dissected using entomological dissecting pins under a stereo microscope. The wings and legs of each mosquito were removed while the remaining part was dissected by placing it on a clean grease-free slide containing a drop of normal saline which was substituted for distilled water. The ovarian tracheoles was then observed to determine if the female was parous or nulliparous (Detinova, 1962). The uncoiled ovarian 
tracheoles are referred to as nulliparous while the coiled as parous.

\subsection{Statistical Analysis}

Analysis of variance was used to test the significant difference in the densities of the weekly-collected mosquito species. It was also used to test for significant differences in the parity rates of the different species.

\section{RESULTS}

A total of 516 female mosquitoes comprising of 4 species were collected during the study period. They were; Anopheles gambiae, Anopheles funestus, Culex quinquefasciatus and Culex annulioris (Table 1). Out of the 4 species, Culex quinquefasciatus, 317 (61.43\%), was the highest collected species followed by Anopheles gambiae (s.1), with a total number of 155 (30.04\%). Culex annulioris was the least with a total number of $5(0.97 \%)$. There was no significant difference in the density of the 4 mosquito species $(p>0.05)$. The table 2 showing the abdominal grading of the various mosquito species reveals $217(42.05 \%)$ mosquitoes fed, $140(27.13 \%)$ half-gravid, 81 $(15.70 \%)$ unfed and $78(15.12 \%)$ gravid. The fed mosquitoes are higher than the unfed mosquitoes. Fed and unfed mosquitoes were seen in An. gambiae,An. funestus and Culex quinquefasciatus but Culex annulioris were only fed, $4(80.00 \%)$ and gravid, $1(20.00 \%)$. Variations in the abdominal grading/gonotrophic stages of the mosquitoes was not significant $(\mathrm{P}>0.05)$. The number of parous mosqutioes is higher than nulliparous mosquitoes. Culex quinquefasciatus has the highest number of parous 108 $(53.2 \%)$ and nulliparous mosquitoes $46(54.8 \%)$ while Culex annulioris has the least $1(0.5 \%)$ and $3(3.6 \%)$ respectively. It has also been observed that the total number of parous and nulliparous mosquitoes decreased down the weeks. Variations in the parity rates of the different species were significant $(\mathrm{p}<0.05)$.

Table.1: Species composition of adult female mosquitoes collected during the studies

\begin{tabular}{|c|c|c|c|c|c|}
\hline Weekly collection & $\begin{array}{l}\text { Anopheles } \\
\text { gambiae } \\
(\%)\end{array}$ & $\begin{array}{l}\text { Anopheles } \\
\text { funestus } \\
(\%)\end{array}$ & $\begin{array}{l}\text { Culex } \\
\text { quinquefasciatus } \\
(\%)\end{array}$ & $\begin{array}{l}\text { Culex } \\
\text { annulioris } \\
(\%)\end{array}$ & $\begin{array}{l}\text { Total } \\
(\%)\end{array}$ \\
\hline Week one & $\begin{array}{l}66 \\
(42.58)\end{array}$ & $\begin{array}{l}21 \\
(53.85)\end{array}$ & $\begin{array}{l}149 \\
(47.00)\end{array}$ & $\begin{array}{l}4 \\
(80.00)\end{array}$ & $\begin{array}{l}240 \\
(46.51)\end{array}$ \\
\hline Week two & $\begin{array}{l}47 \\
(30.32)\end{array}$ & $\begin{array}{l}15 \\
(38.46)\end{array}$ & $\begin{array}{l}102 \\
(38.18)\end{array}$ & $\begin{array}{l}0 \\
-\end{array}$ & $\begin{array}{l}164 \\
(31.78)\end{array}$ \\
\hline Week three & $\begin{array}{l}42 \\
(27.09)\end{array}$ & $\begin{array}{l}3 \\
(7.69)\end{array}$ & $\begin{array}{l}66 \\
(20.82)\end{array}$ & $\begin{array}{l}1 \\
(20.00)\end{array}$ & $\begin{array}{l}112 \\
(21.71)\end{array}$ \\
\hline Total & $\begin{array}{l}155 \\
(30.04)\end{array}$ & $\begin{array}{l}39 \\
(7.56)\end{array}$ & $\begin{array}{l}317 \\
(61.43)\end{array}$ & $\begin{array}{l}5 \\
(0.97)\end{array}$ & 516 \\
\hline
\end{tabular}

Fcal $=0.28<$ Ftab $=4.35 \quad(\mathrm{P}>0.05)$

Table 2: Gonotrophic stages of the adult female mosquito species

\begin{tabular}{|c|c|c|c|c|c|}
\hline $\begin{array}{l}\text { MOSQUITO } \\
\text { Species }\end{array}$ & $\begin{array}{c}\text { Anopheles gambiae } \\
(\%)\end{array}$ & $\begin{array}{l}\text { Anopheles funestus } \\
\qquad(\%)\end{array}$ & $\begin{array}{c}\text { Culex } \\
\text { quinquefasciatus } \\
(\%)\end{array}$ & $\begin{array}{l}\text { Culex annulioris } \\
(\%)\end{array}$ & Total \\
\hline Unfed & $\begin{array}{c}20 \\
(12.90)\end{array}$ & $\begin{array}{c}7 \\
(17.95)\end{array}$ & $\begin{array}{c}54 \\
(17.03)\end{array}$ & $\begin{array}{l}0 \\
-\end{array}$ & $\begin{array}{c}81 \\
(15.70)\end{array}$ \\
\hline Fed & $\begin{array}{c}83 \\
(53.55) \\
\end{array}$ & $\begin{array}{c}18 \\
(46.15) \\
\end{array}$ & $\begin{array}{c}112 \\
(35.33)\end{array}$ & $\begin{array}{c}4 \\
(80.00)\end{array}$ & $\begin{array}{c}217 \\
(42.05) \\
\end{array}$ \\
\hline Half-gravid & $\begin{array}{c}34 \\
(21.94) \\
\end{array}$ & $\begin{array}{c}10 \\
(25.64) \\
\end{array}$ & $\begin{array}{c}96 \\
(30.28) \\
\end{array}$ & $\begin{array}{l}0 \\
- \\
\end{array}$ & $\begin{array}{c}140 \\
(27.13) \\
\end{array}$ \\
\hline Gravid & $\begin{array}{c}18 \\
(11.61) \\
\end{array}$ & $\begin{array}{c}4 \\
(10.26) \\
\end{array}$ & $\begin{array}{c}55 \\
(17.35) \\
\end{array}$ & $\begin{array}{c}1 \\
(20.00) \\
\end{array}$ & $\begin{array}{c}78 \\
(15.12) \\
\end{array}$ \\
\hline Total & $155(30.04)$ & $39(7.56)$ & $317(61.43)$ & $5(96.9)$ & 516 \\
\hline
\end{tabular}

Fcal $=2.42<$ Ftab $=3.49 \quad(\mathrm{P}>0.05)$ 


\section{Table.3: Percentage of parous and nulliparous adult female mosquito species collected}

\begin{tabular}{|c|c|c|c|c|c|c|c|c|c|c|}
\hline \multirow{2}{*}{ 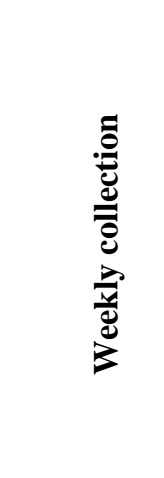 } & \multicolumn{2}{|c|}{$\begin{array}{c}\text { Anopheles gambiae } \\
(\%)\end{array}$} & \multicolumn{2}{|c|}{$\begin{array}{c}\text { Anopheles funestus } \\
(\%)\end{array}$} & \multicolumn{2}{|c|}{$\begin{array}{c}\text { Culex quinquefasciatus } \\
(\%)\end{array}$} & \multicolumn{2}{|c|}{$\begin{array}{c}\text { Culex annulioris } \\
(\%)\end{array}$} & \multirow{2}{*}{ 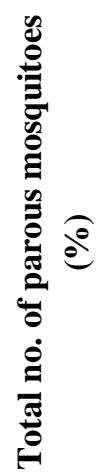 } & \multirow{2}{*}{ 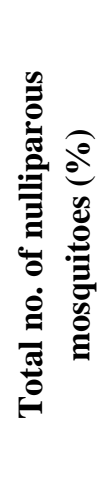 } \\
\hline & $\mathbf{P}$ & NP & $\mathbf{P}$ & NP & $\mathbf{P}$ & NP & $\mathbf{P}$ & NP & & \\
\hline Week one & $\begin{array}{c}29 \\
(37.7)\end{array}$ & $\begin{array}{c}10 \\
(52.6)\end{array}$ & $\begin{array}{c}11 \\
(73.3)\end{array}$ & $\begin{array}{c}4 \\
(66.7)\end{array}$ & $\begin{array}{c}46 \\
(42.6)\end{array}$ & $\begin{array}{c}21 \\
(45.7)\end{array}$ & $\begin{array}{c}1 \\
(100.0)\end{array}$ & $\begin{array}{c}2 \\
(66.7)\end{array}$ & $\begin{array}{c}87 \\
(42.9)\end{array}$ & $\begin{array}{c}37 \\
(44.0)\end{array}$ \\
\hline Week two & $\begin{array}{c}24 \\
(31.2)\end{array}$ & $\begin{array}{c}4 \\
(21.1)\end{array}$ & $\begin{array}{c}6 \\
(75.0)\end{array}$ & $\begin{array}{c}2 \\
(33.3)\end{array}$ & $\begin{array}{c}44 \\
(40.7)\end{array}$ & $\begin{array}{c}19 \\
(41.3)\end{array}$ & $\begin{array}{l}0 \\
-\end{array}$ & $\begin{array}{l}0 \\
-\end{array}$ & $\begin{array}{c}74 \\
(36.4)\end{array}$ & $\begin{array}{c}25 \\
(29.8)\end{array}$ \\
\hline Week three & $\begin{array}{c}24 \\
(31.2)\end{array}$ & $\begin{array}{c}5 \\
(26.3)\end{array}$ & $\begin{array}{c}1 \\
(100.0)\end{array}$ & $\begin{array}{l}0 \\
-\end{array}$ & $\begin{array}{c}18 \\
(16.7)\end{array}$ & $\begin{array}{c}6 \\
(13.0)\end{array}$ & $\begin{array}{l}0 \\
-\end{array}$ & $\begin{array}{c}1 \\
(33.3)\end{array}$ & $\begin{array}{c}43 \\
(21.2)\end{array}$ & $\begin{array}{c}12 \\
(14.3)\end{array}$ \\
\hline Total & $\begin{array}{c}77 \\
(38.0)\end{array}$ & $\begin{array}{c}19 \\
(22.6)\end{array}$ & $\begin{array}{c}18 \\
(8.9)\end{array}$ & $\begin{array}{c}6 \\
(7.1)\end{array}$ & $\begin{array}{c}108 \\
(53.2)\end{array}$ & $\begin{array}{c}46 \\
(54.8)\end{array}$ & $\begin{array}{c}1 \\
(0.5)\end{array}$ & $\begin{array}{c}3 \\
(3.6)\end{array}$ & 203 & 84 \\
\hline
\end{tabular}

$P=$ Parous and $N P=$ NulliparousFcal $=3.5>$ Ftab $=3.50 \quad(\mathrm{P}<0.05)$

\section{DISCUSSION}

Mosquito-borne diseases still remain a major public health problem in Nigeria and their transmission is becoming frequent on daily basis due to widespread of mosquitoes as a result of increasing breeding sites and conducive environments. The presence of the four species of mosquitoes found in the study is an indication that the climatic and environmental condition of the female hostel is conducive to support their breeding, development and survival. The relatively high density collected during the study period indicates the preponderance of breeding sites around the area and this implicates the observed lapses in sanitary conditions; aiding the preponderance of stagnant water bodies around the hostel.

The most abundant mosquito species collected was Culex quinquefasciatus. This could be most likely explained by the presence of large blocked drainages with very dirty stagnant water, ground collections of dirty water, soak-away pits among others which serve as their breeding grounds. This result is in agreement with the study of Adeleke et al. (2010) who recordedCulex quinquefasciatus to be the second predominant species of mosquitoes occurring in Abeokuta. Also, Okorie et al., (2011), recorded Culex species (98\%) as the most abundant of all the mosquito species in Ibadan. The environment however, may not have favoured $C$. annulioris, that may be the reason why the species has the least occurrence.

On the other hand, a good number of Anopheles species were collected. Although the density is quite reduced compared to the results of Onyido et al. (2008) who recorded $69.45 \%$ of Anopheles gambiae and $15.27 \%$ of Anopheles funestus in indoor collection in the same. The reduction of the number may be as a result of government sponsored intervention programmes that have taken place to control mosquitoes for some years now, example is indoor residual spraying (IRS) and sharing of insecticide treated mosquitoes nets. No matter the number, it is still a source of threat to the students staying in the hostels.

The need for blood by adult female mosquitoes to develop their eggs is one of the reasons that they have become successful vectors of tropical diseases. Results from the study shows that much more mosquitoes were bloodfed. Thus, a greater percentage of the mosquitoes have had contact with human host during bloodfeeding and as such, there could be a greater tendency of the infected mosquitoes to have transmitted parasites like Plasmodium and/or filarial 
worms that cause malaria and filariasis respectively which are the two important human tropical infections that are endemic in Africa (Ejezie and Akpan, 1992). The proportion of Anopheles gambiae and Culex quinquefasciatus that were fed were higher than the other $A$. funestus and $C$. annulioris. This was not surprising as both species are anthropophilic. This finding was observed by Ebenezer et al. (2013) during a similar study in some parts of Bayelsa state and by Adeleke et al. (2010) in Abeokuta. The high percentage of bloodfed mosquitoes clearly shows that the two genera; Anopheles and Culex, are not just endophagic but also endophilic as they were caught while resting in their hidden corners.

Consequently, there was high rate of parous females which is in accordance with the recorded $75 \%$ of parous mosquitoes collected indoors by Uttah et al. (2013) at Ekorinim area of Calabar, Cross River state and contrasted with Adeleke et al.(2010) who recorded higher percentage of nulliparous mosquitoes which he explained could be as a result of high productivity of their breeding sites. The present result suggest that majority of the mosquitoes were able to obtain a bloodmeal and complete at least one or more gonotrophic cycles and thus indicates high survival rate and high vectorial capacity of disease transmission as only the parous flies could transmit diseases. Also the majority of the mosquitoes being parous indicate that there are older populations of them which might be as a result of failure or reduced application of vector control measures and interventions in the hostel and its environs. It may also be those who have resisted and survived the methods of intervention.

Parity among mosquitoes may have a bearing on disease circulation. This is because mosquitoes that have already acquired pathogens while feeding, have increase tendency of transmitting these pathogens especially parasites when they seek a fresh bloodmeal. According to Hardy et al. (1983), mosquito feeding behaviour under different ecological conditions may contribute to its longevity and consequently influence the transmission of mosquito-borne diseases. Thus, the more frequent a mosquito bloodfeed, the more likely will it transmit diseases.

\section{CONCLUSION}

The relative high density of mosquitoes encountered in this study is source of threat to the students and therefore is of public health concern. The high percentage of fed and parous mosquitoes also encountered exposes the students to suffering mosquito-borne diseases being transmitted by them which they have little or no natural resistance to and consequently affects their academics for a reasonable period of time. Strong emphasis should be laid on the importance personal protection and environmental hygiene in the University environment and hostel management should make it a policy which every student should abide by.

\section{ACKNOWLEDGEMENT}

We acknowledge the assistance of the hostels Management of Nnamdi Azikiwe University (NAU) as well as those of the laboratory staff of the Department of Parasitology and Entomology, NAU, Awka.

\section{REFERENCES}

[1] Adeleke, M.A., Mafiana, C.E., Idowu, A.B., Sam-Wobo, S.O. and Idowu, O.A. (2010).Population dynamics of indoor sampled mosquitoes and their implication in disease transmission in Abeokuta, South-western Nigeria. Journal of Vector Borne Disease. 47, 33-38.

[2] Anosike, J.C., Onwuluri, C.O.E., Nwoke, B.E.B. and Dozie, I.N.S. (2003). Laboratory investigation of the infection rates of Anopheles gambiae and Anopheles funestus in the transmission of Wuchereria bancrofti. Nigerian Journal of Parasitology. 24,153-158.

[3] Awolola, T., Idowu, E., Adeneye, A., Maje, M., Oduola, A. and Ogunrinade, A. (2006).Entomological survey and infection rates of Plasmodium falciparum and Wuchereria bancrofti in mosquito populations in the Kainji lake area, Nigeria.Nigerian Journal of Parasitology. 27, 58-61.

[4] Burkot, T., Garner, P., Paru, R., Dagora, H., Barnes, A. and McDouga, I.I.S. (1990). Effects of untreated bednets on the transmission of Plasmodium falciparum, Plasmodium vivax and Wuchereria bancrofti in Papua New Guinea. Transfer Royal Society of Tropical Medical Hygiene. 84, 773-779.

[5] David, M.R., Ribeiro, G.S. and Freitas, R.M. (2012). Bionomics of Culex quinquefasciatus within urban areas of Rio de Janeiro, south-eastern Brazil. Rev Saide Publica. 46, 858-865.

[6] Davidson, G. (1954). Estimation of the survival rate of anopheline mosquitoes in nature. Nature. 174, 792-793.

[7] Detinova, T.S. (1962). Age grading methods in diptera of medical importance with special reference to some vectors of malaria. World Health Organisation, Geneva, Switzerland. 47, 1-216.

[8] Ebenezer, A., Ben, H.I.B. and Enaregha, E.B. (2013). Atial distribution and indoor-resting density of mosquito species in the lowland rainforest of Bayelsa state, 
Nigeria. International Journal of Tropical Medicine. 8(4), 87-91.

[9] Ejezie, G.C. and Akpan, I.E. (1992). Human ecology and parasitic infections 1: The effect of occupation on the prevalence of parasitic infections in Calabar. Journal of Epidemiology, Microbiology and Immunolgy. 36(2), 161-168.

[10] Fouque, F., Carinci, R., Gabont, P., Issaly, J., Bicout, D.J., Sabatur, P. (2006).Anopheles gambiae survival and malaria transmission patterns in French Guiana. Journal of Vector Ecology. 31, 390-399.

[11] Garret-Jones, C. and Grab, B. (1994). The assessment of insecticidal impact on the malaria mosquito vectorial capacity, from data on the proportion of parous females. Bull World Health Organisation. 31, 71-86.

[12] Gillet, J.D. (1972). Common African mosquitoes and their medical importance. William Heinemann Medical Books 1.t.d .London:UK. 1, 10-12.

[13] Hardy, J.L., Houk, E.J., Kramer, L.D. and Reeves, W.C. (1983). Intrinsic factors affecting vector competence of mosquitoes for arboviruses. Annuals of Revised Entomology. 28(1), 229-262.

[14] Harrington, L.C., Francoisevier, M., Jones, J.J., Kitthawei, S., Sethiprasasna, R., and Edman, J.D. (2008). Age-dependent survival of the malaria vector, Anopheles gambiae (Diptera: Culicidae) demonsrated by simultaneous release-recapture of different age cohorts. Journal of Medical Entomology. 45, 307-313.

[15] Hotez, P.J., Asojo, O.A. and Adesina, A.M. (2012). Nigeria: "Ground Zero" for high prevalence of neglected tropical diseases. PLOS Neglected Tropical Diseases. 6, e1600.

[16] Iloeje, N.P. (2001). A new geography of Nigeria, a new revisited edition. Longman Nigeria p.l.c, Ikeja. Pg 199.

[17] Kuno, G. (1995). Review of the factors modulating dengue transmission. Epidemiological Revolution. 17, 321-335.

[18] Lehane, M.J. (2005). The biology of blood-sucking insects. Cambridge University Press. Pg 321.

[19] Maciel-de-Freitas, R., Codeio, C.T., Lourinco-deOliveira, R. (2007). Daily survival rate and dispersal of
A. gambiae females in Rio de Jaineiro, Brazil. American Journal of Medical Hygiene. 76, 659-665.

[20] Okorie, P.N., McKenzie, F.E., Ademowo, O.G., Bockarie, M. and Kelly-Hope, L. (2011). Nigeria Anopheles vector database: an overview of 100 years research. PLOS ONE.6, e28347.

[21] Onyido, A.E., Deezia, N.P.L., Obiukwu, M. and Amadi, E. (2008). Ecology of man-biting mosquitoes in the development site of Nnamdi Azikiwe University, Awka, Anambra state, South-eastern Nigeria. The Internet Journal of Health. 9(2), 1-7.

[22] Presidents Malaria Initiative- PMI (2013). Nigerian malaria operational plan.Pg 1-60. (2013).

[23] Saifur, R.G.M., Deing, H., Hassan, A.A., Salmah, M.R.C., Satho, T. and Miake, F. (2012). Changing domesticity of Aedesaegypti in northern Pennisular, Malaysia: Reproductive consequences and potential Epidemiological implications. PLOS ONE.7(2), e30919.

[24] Scott, T.W. and Takken, W. (2012). Feeding strategies of anthropophilic mosquitoes result in increased risk of pathogen transmission. Trends in Parasitology. 28, 114121.

[25] Pan, C.P. and Yasuno, M. (1973). Field studies on the gonotrophic cycle of Culex quinquefasciatus in Bangkok, Thailand. Journal of Medical Entomology. 10, 219-223.

[26] Uttah, E.C., Iboh, C.I., Ajang,R., Osim, S.E. and Etta, H. (2013). Physiological age composition of female anopheline mosquitoes in an area endemic for malaria and filariasis. International Journal of Scientific and Research Publications. 3(7), 1-4.

[27] Word Health Organization (1994). Guide on medical Entomology on malaria part 2, methods and techniques.World Health Organization, Geneva. Pg 226.

[28] Word Health Organization (2010). Progress report 20002009 and strategic plan 2010-2020 of the global programme to eliminate lymphatic filariasis.Pg 6 .

[29] Word Health Organization (2015). Fact Sheet: World Malaria Report 2015. Global Technical Strategy for Malaria 2016-2030 